\title{
Asas Itikad Baik Sebagai Upaya Perlindungan Hukum terhadap Pelaku Usaha \\ Dalam Pembiayaan Konsumen (Studi Putusan Mahkamah Agung Republik Indonesia Nomor 1041 K/Pdt.Sus-BPSK/2017)
}

\author{
Arfi Azhari \\ (Mahasiswa Program S1 Fakultas Hukum Universitas Tarumanagara) \\ (E-mail: arfiazhari11 @gmail.com)
}

\section{Siti Nurbaiti}

(Corresponding Author)

(Dosen Fakultas Hukum Universitas Tarumanagara, Mendapatkan Gelar Sarjana Hukum pada Fakultas

Hukum Universitas Trisakti, Sarjana Sastra Jurusan Arkeologi di Universitas Indonesia, Magister

Hukum Bisnis pada Fakultas Hukum Universitas Tarumanagara, dan Doktor Ilmu Hukum di Universitas Trisakti)

(E-mail: nurbaiti_05092000@yahoo.com)

\begin{abstract}
Consumer Finance is a financing activity for the procurement of goods based on consumer needs with payment in installments. In consumer financing, the parties must have good intentions for the smooth running of the agreement, but in practice the principle of good faith is often violated by the parties such as in the Decision of the Supreme Court of the Republic of Indonesia No. 1041 / K-Pdt.Sus-BPSK/2017 decides to grant a request from Martha Sitorus (consumer) with consideration of Article 2 of the UUPK and the principle of good faith, which in this case with the existence of the decision clearly has harmed PT. Toyota Astra Financial Service Medan (business actor) for consumer financing agreements. The problem studied is how the legal protection of business actors carried out by consumers in consumer financing and how the RI Decision No. 1041 / K-Pdt.Sus-BPSK/2017 towards legal protection of business actors carried out by consumers in consumer financing. The research method used is a normative method supported by interview data. The results of the writing illustrate that the business actor does not receive legal protection as stipulated in Article 6 letter (b) UUPK and in the Decision of the Supreme Court of the Republic of Indonesia No. 1041 / K-Pdt.Sus-BPSK/2017 The Panel of Judges is not right in making decisions.
\end{abstract}

Keywords: Consumer Financing, Principle of Good Faith. 


\section{PENDAHULUAN}

\section{A. Latar Belakang}

Perkembangan dunia meningkatkan banyaknya kebutuhan yang harus di penuhi oleh manusia dan dengan membengkaknya suatu kebutuhan itu dapat menggerakan kegiatan investasi ekonomi di suatu negara. Setiap perusahaan mempunyai keunggulan dan visi misi dalam menjalankan usahanya dengan tujuan untuk membantu manusia dalam memenuhi kebutuhannya. Masyarakat yang berpenghasilan dibawah rata-rata menyebabkan hal ini menjadi suatu masalah dimana dalam memenuhi kebutuhannya mereka mengambil jalan untuk membeli kebutuhannya dengan secara angsuran. Masyarakat yang menginginkan suatu kebutuhan dapat melakukan perjanjian dengan suatu perusahaan pembiayaan yang dimana perusahaan pembiayaan menyediakan layanan jasa dalam bentuk kredit. Klien dari perusahaan pembiayaan biasanya melaksanakan transaksi jual-beli dengan perusahaan pembiayaan seperti pembiayaan kendaraan, peralatan elektronik, dan lain-lainya.

Pembiayaan konsumen merupakan suatu bentuk yang, biasanya dalam bentuk kontrak atau undang-undang. ${ }^{1)}$ Kontrak ini merupakan inti dari jalannya suatu pembiayaan konsumeen. Dalam pembiayaan konsumen terdapat suatu kontrak dirancang antara suatu pembiayaan perusahaan dengan kliennya, yang akan pembiayaan perusahaan memberikan dana untuk membeli suatu objek dari pihak ketiga, untuk digunakan oleh klien, dan klien ini mempunyai kewajiban membayar pinjaman, baik berupa pinjaman pokok, berdasarkan waktu yang disepakati antar pihak. $^{2)}$

1) AbdulKadir Muhammad dan Rilda Murniati, Segi Hukum Lembaga Keuangan dan Pembiayaan, (Bandung: Citra Aditya Bakti, 2000). hal. 51.

${ }^{2)}$ H.Salim HS, Perkembangan Hukum Kontrak Di luar KUH Perdata Buku Dua, (Jakarta: PT Raja Grafindo Persada, 2008), hal. 130-131. 
Bentuk jaminan atas konsumen pembiayaan intinya serupa seperti kredit bank dengan bentuk jaminannya. Ada beberapa bentuk dari jaminan yaitu pertama awal jaminan, kedua pokok jaminan dan tambahan jaminan. ${ }^{3)}$ berikut uraian dari beberapa jaminan, yang pertama adalah awal jaminan ialah jaminan yang berasal dari perusahaan pembiayaan yang menyeleksi calon kliennya. Jadi diawal jaminan ini terdapat ketentuan atas pembuatan kartu kredit, seperti dilihat dari prinsiip 5C (Collaterall, Capacityy, Characterr, Capitall, Condition of Economyy.), Kedua pokok jaminan, ialah dimana yang menjadi objek jaminan ini apa yang telah disetujui dari perusahaan pembiayaan dengan klienya, seperti suatu kendaraan yang dijadikan pokok jaminan. Seperti suatu hal yang telah menjadi kebiasaan pokok jaminan di bentuk dengan Fiduciary Transfer of Ownership (FTOF/Fidusia). Keberadaan Fidusiaa menjadikan arsip/salinan terkait pemilikan objek yang wajib diserahkan kepada perusahaan pembiayaan sampai lunas kreditnya. Perjanjian merupakan kejadian antaraa satu pihak atau banyak menghubungkan dalam ketentuan yang spesifik dengan pihak lain. Berdasarkan kejadian itu, akan adanya ikatan antar pihak. Dalam objeknya, perjanjian ialah suatu kerangka perkataan dan tulisan dimana yang mengartikan kesanggupan dan janji yang dituliskan dari beberapa orang. ${ }^{4)}$

Berdasarkan pedoman dalam kitab undang-undang hukum perdata pengertian perjanjiaan yaitu sesuatu tindakan dimana seseorang pihak dan banyak pihak saling memiliki suatu ikatan dengan pihak lain dan banyak pihak. Perumusan ini menyebabkan ketentuan aturan dimana dalam perjanjian ini wajib hadir dua orang, dimana satu orang mempunyai kewajiban untuk memenuhi hak dan kewajiban orang lain yang memiliki ikatan perjanjian. ${ }^{5)}$

${ }^{3)}$ Munir Fuady, Hukum tentang Pembiayaan (dalam teori dan praktek), (Bandung: Citra Aditya Bakti, 2002), hal. 168.

4) Subekti, Hukum Perjanjian, (Jakarta: Intermasa, 1997), hal. 1.

5) Kartini Muljadi dan Gunawan Widjaja, Perikatan Yang Lahir dari Perjanjian, (Jakarta: Rajawali Pers, 2013), hal. 35. 
Adapun ketentuan sah dari kontrak didalam kitab undang-undang hukum perdata harus memenuhi kriteria berikut: ${ }^{6)}$ Pertama adanya sepakat dari satu orang dengan orang yang lain, sepakat disini dapat diartikan sebagai, bahwa satu orang itu dengan orang yang lain telah memiliki satu tujuan, kehendak yang sama yang dimana untuk menyatukan tujuan itu tidak dengan keterpaksaan dan tipu muslihat.

Kedua cakap dalam menciptakan perikatan, cakap (beekwaam) ketentuan yang bersifat yang harus ada karena hal ini guna menciptakan ikatan hukom yang di anggap sah, ialah wajib berusia yang dapat dikatakan sudah bukan anak kecil lagi atau disebut usia dewasa, tidak memiliki gangguan jiwa dan juga tidak bertrntangan dengan hukom. Ketentuan cakaap bagi sesorang dimana ia dapat melaksanakan suatu ikatan dengan orang lain dengan tidak membahayakan orang lain dan juga dirinya sendiri.

Ketiga adanya objek yang diperjanjikan, pada perjanjian harus ada objek yang akan dipakai. Menurut kitab undang-undang hukum perdata objek yang akan dipakai dalam perjanjian ini harus ada dan dapat dipertanggungjawabkan serta dipertimbangkan. Selanjutnya dalam kitab undang-undang hukum perdata dispesifikasikan bahwa objek yang akan digunakan ini harus jelas, rinci dan spesifik. Didalam kitab undang-undang hukum perdata ada suatu larangan dimana objek yang diperjanjikan ini tidak boleh berasal dari objek pewarisan.

Keempat ada dimana objek yang diperjanjikan ini tidak bertentangan dengan peraturan hukom yang berlaku, hal ini berguna agar objek yang diperjanjikan ini menjadikan perjanjian menjadi sah. Perihal syarat ini di kitab undang-undang hukum perdata berpendapat bahwa perjanjian yang dibuat dengan objek bertentangan dengan peraturan yang berlaku, maka perjanjian itu tidak memiliki kekuatan hukum.

6) Riduan Syahrani, Seluk Beluk dan Asas-Asas Hukum Perdata, (Bandung: Alumni, 2006), hal. 205-213. 
Berdasarkan kejadian yang telah diuraikan itu akan terbitlah suatu hubungan antara orang yang satu dengan orang yang lain dan didalam hubungan itu kalau orang yang satu tidak melaksanakan kewajibannya maka orang yang lain bisa menuntut hak nya untuk dipenuhi. Ikatan hukum antara orang-orang yang membuat suatu perjanjiann tersebut bersifat ikatan hukum perseorangan (persoonlijke), dan bukan hubungan hukum yang bersifat kebendaan (zaakelijke). ${ }^{7)}$ Kenyataan yang ada di masyarakat seseorang pasti berhubungan dengan orang yang lain, seperti hal nya jual-beli dimana hal itu merupakan suatu peristiwa hukum dimana didalamnya ada perbuatan hukum antara dua orang dalam suatu transaksi dengan sebuah objek yang diperjanjikan, dan dalam jualbeli itu harus ada itikad baik dimana agar terlaksananya jual-beli tersebut. Karna kalau hak itu tidak dilaksanakan dengan itikad baik, rawan terjadi sengketa atas perjanjian jual-beli tersebut. ${ }^{8)}$

Kententuan awal itikad baik pada biasanya sudah menjadi landasan fundamental bagi pelaksanaan dan pembikinan kontrak, karena kalau tanpa didasarkan itikad baik orang yang melaksanakan perjanjian itu harus mengutamakan kejujuran, kejujuran disi diartikan seseorang harus memberikan suatu keterangan yang benar dan tidak ada kebohongan dalam melaksanakan perjanjian. Itikad baik ini berguna untuk kedua orang yang melaksanakan perjanjian karena hal ini mencerminkan dari asas konsensualissme yang ada pada perjanjian. ${ }^{9)}$

7) Luh Nila Winarni, “Asas Itikad Baik Sebagai Upaya Perlindungan Konsumen Dalam Perjanjian Pembiayaan”, Jurnal Ilmu Hukum, Vol. 11, No. 21 Tahun 2015, hal. 3.

${ }^{8)}$ R.Wirjono Prodjodikoro, Asas-asas Hukum Perjanjian, (Bandung: Mandar Maju, 2002), hal. 102.

${ }^{9)}$ I Gusti Agung Wisudawan. "Prinsip Itikad Baik Para Pihak Dalam Perjanjian Kredit Sebagai Upaya Meminimalisasi Terjadinya Kredit Bermasalah Pada Lembaga Keuangan Koperasi ", Gane Swara, Vol. 7, No.2, Tahun 2013, hal. 58 
Asas itikad baik diterapkan dalam perjanjian diperhatikan terutama dalam melakukan perjanjiann awal, karena di awal ini itikad baik dipenuhi dengan suatu ketentuan sah suatu perjanjian dan juga menghindarkan dari adanya suatu kerugian didalam perjanjian. Didalam undang-undang perlindungan konsumen (UUPK) memyatakan bahwa itikad baik ini harus ada diantara konsumen dan pelaku usaha dalam melaksanakan suatu transaksi perjanjian, karena kalau terjadi sengketa parapihak dapat meminta tanggung jawab dan ganti rugi. ${ }^{10)}$

Asas itikad baik dapat dibedakan berdasarkan 2 bentuk, yaitu bentuk pertama, itikad baik dilihat secara subjektif dimana itikad baik dilihat dari hati seseorang dalam melaksanakan perjanjian, yang dimaksud dari hati yaitu kejujuran seseorang dalam melaksanakan perjanjian. Kedua bentuk itikad baik dapat dilihat secara objektif dimana itikad baik disini dilihat dari keadaan lingkungan seseorang yang membuat suatau perjanjian apakah hal yang diperjanjikan itu dapat diterima dan tidak bertentangan dengan lingkungan masyarakat pada umumnya. ${ }^{11)}$

Konsumen dan pelaku usaha biasanya dalam membentuk perjanjian yang sah, terkadang konsumen tidak memahami bentuk perjanjiann dan syarat-syarat perjanjian. Konsumen kurang paham dengan perjanjian yang ada, misalkan notaris dengan seseorang mendaftarkan perjanjian itu ke notaris berguna untuk memperkuat isi suatu perjanjian. Pelaku usaha \& konsumen yang terhubung didalam perjanjian yang baik misal dalam perjanjian pembiayaan konsumen dengan uang tunai di perusahaan pembiayaan dimana konsumen harus memenuhi suatau ketentuan 5C, yakni Character, Capacity, Capital Condition Of Economy Collateral. $^{12)}$

10) Suharnoko, Hukum Perjanjian Teori dan Analisa Kasus, (Jakarta: Prenada Media, 2014), hal. 5. 62.

11) R. Wirjono Prodjodikoro, Asas-Asas Hukum Perdata, (Bandung: Sumur, 1992), hal. 56-

${ }^{12)}$ Sunaryo, Hukum Lembaga Pembiayaan, (Jakarta: Sinar Grafika, 2009), hal. 105. 
Dilaksanakan ketentuan atau tidak dilaksanakan ketentuan tersebut akan berdampak pada klien perusahaan pembiayaan, syarat tidak terpenuhi berdampak atas timbulnya sanksi kepada klien perusahaan pembiayaan. Perusahaan pembiayaan dapat memeberikan sanksi kepada kliennya yaitu berupa penarikan objek yang diperjanjikan atau gugatan ke pengadilan. Dan dari itu konteks perlindungan hukum kedua belah pihak itu harus seimbang guna terlaksananya perjanjian. Seperti perkara yang ada pada Putusan MA RI No.1041 K/Pdt.SusBPSK/2017) dimana ada pihak bersengketa antara Martha Sitorus (yang selanjutnya disebut konsumen) melawan PT. Toyota Astra Finance Service Medan dan PT. Toyota Astra Auto 2000 (yang selanjutnya disebut konsumen). Kasus yang ada dalam putusan tersebut dimana pihak konsumen tidak melakukan cicilan tunggakan (wanprestasi) dengan pelaku usaha dan juga melanggar unsur dari kejujuran, kepatuhan dan kepatutan.

Konsumen pertama kali mengajukan permasalahanya ke BPSK kota Medan, dilanjutkan ke Pengadilan Negeri Medan dan terakhir di Mahkamah Agung. Pertama di BPSK Medan akhirnya pada putusan No.17/ARB/2016/BPSK-Medan menolak gugatan konsumen karena dengan alasan surat gugatan konsumen belum memenuhi syarat materiil, gugatan konsumen yaitu syarat mutlak menuntut ganti rugi sebagaimana dimaksud didalam Pasal 19 UUPK karena objek di persengketakan masih ada pada konsumen.

Konsumen megajukan keberatan kembali pada Pengadilan Negeri Medan pada Putusan No.188/Pdt.Sus.BPSK/2016/Pn.Mdn. Tepatnya pada 15 Agustus 2016 Pengadilan Negeri Medan menjatuhkan putusan yaitu mengabulkan gugatan pelaku usaha untuk seluruhnya dan menyatakan konsumen telah melakukan perbuatan cidera janji (wanprestasi) serta mengeluarkan surat untuk 
pernarikan objek yang dipersengketakan yang ada pada konsumen, akan tetapi saat pelaku usaha akan menarik objek yang dipersengketakan ternyata objek tersebut ada dipihak ketiga dimana hal ini sangat jelas telah merugikan pelaku usaha.

Konsumen yang kurang puas dengan putusan tersebut langsung mengajukan permohonan kasasii pada tanggal 29 Agustus 2016 dengan No. 74/Pdt/Kasasi/2016/Pn.Mdn yang akhirnya menjatuhkan putusan pada 19 Oktober 2017 No.1041 K/Pdt.Sus-BPSK/2017, dengan amarr pertama menerima permohonan kasasi dari (Martha Sitorus/konsumen) selaku pemohon kasasi, kedua mengugurkan putusan Pengadilan Negeri Medan Nomor 188/Pdt.Sus.BPSK/2016/Pn.Mdn, pada 15 Agustus 2016.

Berdasarkan hal-hal telah diuraikan, maka dilakukan penelitian dan menuangkan pada karya ilmiah dalam bentuk skripsi dengan judul "Asas Itikad Baik Sebagai Upaya Perlindungan Hukum Terhadap Pelaku Usaha Dalam Pembiayaan Konsumen (Studi Putusan Mahkamah Agung Republik Indonesia Nomor.1041 K/Pdt.Sus-BPSK/2017)".

\section{B. Permasalahan}

Berdasarkan uraian latar belakang, maka permasalahan yang hendak diteliti adalah:

1. Bagaimana perlindungan hukum terhadap pelaku usaha dari tindakan konsumen dalam pembiayaan konsumen?;

2. Bagaimana Putusan Mahkamaah Agung Republik Indonesia Nomor 1041 K/Pdt.Sus-BPSK/2017 terhadap perlindungan hukum pelaku usaha dari tindakan kosumen dalam pembiayaan konsumen?.

\section{PEMBAHASAN}

1. Perlindungan Hukum Terhadap Pelaku Usaha Dari Tindakan Konsumen Dalam Pembiayaan Konsumen 
Pembiayaan konsumen Menurut PP Republik Indonesia No.9 Tahun 2009 Tentang Lembaga Pembiayaan Pasal 1 angka 7 menyebutkan Pembiayaan Kosumen (Consumer Finance) adalah kegiatan pembiayaan untuk pengadaan barang berdasarkan kebutuhan konsumen dengan pembayaran secara angsuran. Lebih lanjut dalam peraturan hukum terbaru pembiayaan konsumen sendiri masuk kedalam kategori kegiatan usaha perusahaan pembiayaan di pembiayaan multiguna, pengertian pembiayaan multiguna dalam Pasal 1 angka (3) POJK No.29/POJK/2014 adalah suatu pembiayaan untuk pengadaan barang dan/atau jasa yang diperlukan oleh debitur untuk pemakain/konsumsi dan bukan untuk keperluan usaha (aktivitas produktif) dalam jangka waktu yang diperjanjikan.

Kegiatan usaha pembiayaan multiguna ini dalam Pasal 4 ayat (3) wajib dilakukan dengan cara pertama sewa pembiayaan, kedua pembelian dengan pembayaran secara angsuran; dan/atau, ketiga pembiayaan lain setelah terlebih dahulu mendapatkan persetujuan dari OJK.

Menurut Dr. Munir Fuady, S.H., M.H. Dosen Hukum Lembaga Pembiayaan, Universitas Tarumanagara, menyatakan pembiayaan konsumen ialah aktivitas pembiayaan dalam mengadakan objek berdasarkan keinginan masyarakat digunakan metode pembelian secara berangsur \& bukan seperti yang ada di kredit bank. Pembiayaan konsumen sebagai credit sale adalah pengasihan suatu objek dengan pembelian secara kredit \& klien mendapatkan objek tertentu setelah ia melunasi kewajibannya dalam suatu perjanjian pembiayaan konsumen.

Dasar hukum pembiayaan konsumen menurut beliau tidak ada undangundang akan tetapi pembiayaan konsumen diatur dalam peraturan teknis, jadi yang berlaku adalah karena pembiayaan konsumen diawali dengan sebuah perjanjian berlaku ketentuan hukum perjanjian dalam KUHPerdata buku III yaitu ketentuan tentang hukum perjanjian pada umumnya, disamping beberapa pasal nanti tergantung jenis pembiayaan, karena menurut pembiayaan konsumen ini bidang-bidang nya dibagi sebagai berikut: 
a. Pembiayaan Kendaraan motor dan mobil;

b. Pembiayaan peralatan rumah tangga;

c. Pembiayaan benda elektronik;

d. Pembiayaan Properti seperti rumah.

Hubungan antara kedua belah pihak dalam pembiayaan konsumen beliau menyatakan ada tiga, yang pertama adalah ikatan antara pembiayaan perusahaan dengan konsumen, yang kedua hubungann dengan klien, pihak ketiga \& yang ketiga hubungann antara perusahaan pembiayaan \& pihak ketiga . Selanjutnya beliau menjelaskan karakteristik dari pembiayaan konsumen antara lain pertama sasaran pembiayaan jelas yaitu konsumen yang membutuhkan barang-barang konsumsi, kedua objek pembiayaan barang berupa barang-barang untuk kebutuhan atau konsumsi konsumen, ketiga besarnya pembiayaan yang diberikan oleh perusahaan pembiayaan konsumen relatif kecil sehingga resiko pembiayaan relative lebih aman karena pembiayaan tersebar pada banyak konsumen, keempat pembayaran yang dilakukan oleh konsumen kepada perusahaan pembiayaan konsumen ini biasanya dilaksanakan berdasarkan angsuran.

Beliau juga menjelaskan dari keutamaan pembiayaan konsumen dari dengan kredit bank antara lain, pertama prosedur yang lebih sederhana, proses persetujuan perjanjiann yang sangat mudah, perusahaan pembiayaan konsumen biasanya tidak mensyaratkan penyerahan agunan tambahan sepanjang konsumen cukup layak untuk dipercaya kemampuan dan kemauannya untuk memenuhi kewajibannya.

Beliau juga mengatakan bahwa dalam pembiayaan konsumen ini juga terdapat jaminan, dimana jaminan yang ada dikasih dalam transaksi pembiayaan konsumen ini pada dasarnya mirip dengan jaminan terhadap perjanjian kreditt bank biasa, khususnya kredit konsumsi. Perihal hapusnya kontrak konsumen menurut beliau dimana musnahnya barang yang dibiayai itu tidak menghapuskan kontrak pembiayaan konsumen, sebagai pihak konsumen harus tetap melunasi 
pembayarannya sesuai perjanjian yang sudah disepakati. Dan selain apabila konsumen wanprestasi dalam perjanjian beliau menjelaskan bahwa wanprestasi itu ialah dalam suatu perjanjiann konsumen tidak melakukan yang telah diperjanjikan dan juga konsumen melakukan susuatu hal yang dilarang oleh perusahaan pembiayaan, karena ini dimana pihak perusahaan pembiayaan bisa menggutgat ganti kerugian atau menuntut dengan cara yang lain.

Ada dua inti hukum pembiayaan konsumen yang pertama dalam perdata, \& yang kedua itu ialah UU merupakan inti hukum pembiayaan konsumen juga yang dilihat secara umum. Dalam segi hukum perdata Pembiayaan konsumen ini bersumber pada Pasal 1313 kitab undang-undang hukum perdata yang mengayomi perjanjian antara konsumen \& pelaku usaha, sedangkan dari segi luar hukum perdata pembiayaan konsumen terdapat pada Peraturan Presiden RI No.9 Tahun 2009 Tentang Lembaga Pembiayaan dan Peraturan Otoritas Jasa Keuangan Nomor 29/POJK.05/2014 tentang Penyelenggaraan Usaha Perusahaan Pembiayaan.

Perjanjian pembiayaan konsumen berbentuk perjanjian klausula baku. Menurut UUPK Pasal 1 ayat (10) bahwa klausula baku/ perjanjian baku ialah segala aturan atau ketentuan dan syarat-syarat yang telah disiapkan dan ditetapkan terlebih dahulu secara sepihak oleh pelaku usaha yang dituangkan dalam suatu dokumen dan/ atau perjanjian yang mengikat dan wajib dipenuhi oleh konsumen. Dasar hukum perjanjiann pembiayaan konsumen ini tunduk pada Pasal 1313 dan 1338 ayat (1), (2) dan (3) kitab undang-undang hukum perdata. Seperti kasus antara Martha Sitorus (yang selanjutnya disebut konsumen) dengan PT. Toyota Astra Finance Service (yang selanjutnya disebut pelaku usaha) dimana adanya perjanjian pembiayaan konsumen, khususnya pada pembiayaan kendaraan. Konsumen didalam perjanjian pembiayaan konsumen tersebut tidak melaksanakan pembayaran yang dimana dalam perjanjian itu konsumen diwajibkan untuk membayar kepada pelaku usaha setiap bulannya. 
Pelaku usahaa di kasus ini sama sekali tidak menerima perliindungan hukom atas perjanjian pembiayaan konsuumen dimana, konsumen kurang memenuhi pembayaran dan sebagaimana diamanatkan dalam UUPK Pasal 6 huruf (b) pelaku usaha mempunyai hak untuk mendapatkan suatu perlinduungan hukum dari perilaku konsumen yang beritikad tidak baik. Tindakan konsumen yang tidak melaksanakan itikad baik itu biasanya berupa dimana konsumen tidak melaksanakan pembayaran dari suatu perjanjian yang telah dibuat dengan pelaku usaha atau tindakan dimana konsumen melanggar sesuatu yang telah diperjanjikan dengan pelaku usaha.

Menurut salah satu dosen Hukum Perlindungan Konsumen, Universitas Trisakti, Perlindungan hukum itu bisa berbentuk preventif dan respresif, kalau bentuk perlindungan hukum preventif menurut beliau sudah cukup dari UUPK itu sendiri sebagai contohnya adanya haak dan kewajibannn para pihak, ketentuan larangan pelaku usaha, tanggung jawab pelakuu usaha yang ketika itu tidak dilaksanakan itu ada dampak hukum atau akibat hukumnya misalnya harus memenuhi panggilan atau menjalani pemeriksaan di lembaga-lembaga baik didalam maupun di luar pengadilan, dimana didalam pengadilan itu bisa pengadilan negeri itu sendiri dan diluar pengadilan itu bisa lembaga semacam BPSK, Arbitrase ataupun menggunakan Mediator, jadi tergantung forum lembaga penyelesain sengketa yang dipilih oleh pelaku usaha. Maksud perlindungan hukum bagi pelaku usaha dimana ia harus diberikan hak untuk menjawab, misalnya barang/produk pelaku usaha dipalsukan dan juga ada contoh dimana ada kasus konsumen yang meninggal setelah menggunakan produk dari pelaku usaha, tetapi rupanya konsumen meniggal bukan karena menggunakan produk dari pelaku usaha, dimana ini ada kesempatan pelaku usaha untuk membuktikan.

Menurut beliau di dalam UUPK ini memberikan pembuktian secara berlawanan dalam arti pelakuusaha diberika untuk membuktikan kalau tidak ada 
konsumen yang complain atau mengeluh atas produk dan jasa yang dihasilkan. Sanksi hukum bagi konsumen yang bertindak tidak beritikad baik menurut beliau bahwa pelaku usaha ini bisa menggugat baik sifatnya perdata yakni ganti rugi ataupun menuntut secara pidana yakni perbuatan tidak menyenangkan. Bentuk perlindungan hukum secara represif terhadap pelaku usaha ini dalam pembiayaan konsumen dimana pelaku usaha dapat memberikan sanksi baik secara hukum perdata maupun pidana, dimana dalam bentuk pidana pelaku usaha dapat menuntut konsumen atas tindakan pencemaran nama baik dalam Pasal 310-311 kitab undang-undang hukum pidana. Di dalam hukum perdata pelaku usaha dapat melakukan gugatan wanprestasi. Wanprestasii merupakan kelalaian dan kealpaaan seorang debiturr itu ada empat jenis, pertama tidak melaksanakan yang disanggupi akan dilakukannya, kedua melaksanakan yang dijanjikannya tetapi tidak seperti yang diikatkan, ketiga melaksanakan sesuatu dijanjikan tetapi terlambat, keempat melanggar ketentuan yang ada didalam perjanjian.

Misalkan konsumen dalam melakukan wanprestasi, pelaku usaha bisa melakukan penuntuntutan sebagaimana dalam Pasal 1267 kitab undang-undang hukum perdata, yaitu pelaku usaha dapat memaksakan konsumen untuk membayar kewajibannya sebagaimana yang telah ditentukan dengan Bungan, pelaku usaha dapat meminta ganti kerugiaan atas tindakan konsumen, pelaku usaha dapat melakukan pembatalan perjanjian dengan konsumen. Didalam pasal tersebut ada beberapa sarjana hukum yang menjabarkan lima tuntutan, pertama wajib dipenuhi apa yang telah diperjanjikan, kedua pemenuhan perjanjiaaaan dengan ganti kerugiaan, ketiga hanya dengan ganti kerugiaan, keempat diskualifikasi perjanjian dan kelimaan diskualifikasi perjanjian dengan ganti kerugiaan.

Biaya penggantian, bunga dan kerugiaan dikarena wanprestasi(cidera janji) dapat dilaksanakan apabila konsumen tidak melaksanakan pemenuhan kewajiban sebuah perjanjian, didalam Pasal 1243 kitab undang-undang hukum perdata, 
menyebutkan kalau penggantian biaya kerugian, oleh konsumen kalau ia tidak melaksanakan suatu ketentuan yang ada didalam perjanjiaan dimana hal ini dapat dilihat dari ketentua tenggang waktu yang telah diperjanjikan

Dilihat dari Pasal 1243 kitab undang-undang hukum perdata, terdapat dua metode pemberian titik awal dari ganti kerugian, pertama kalau didalam kontral tidak dispesifikasikan ketentuan jangka waktu, peembelahan kerugiaan pada saat konsumen pertama kali tidak melaksanakan kewajibannya, kedua apabila didalam perjanjian telah ditentukan jangka waktu tertentu, maka suatu pembayaran ganti kerugian dimulai dikalkulasi sejak terlampauinya jangka waktu yang telah ditentukannya.

Berdasarkan analisis dalam kasus pelaku usaha disini telah dirugikan oleh konsumen, dimana konsumen telah melanggar ketentuan didalam Pasal 1338 ayat (3) kitab undang-undang hukum perdata yang mennyatakan kalau ketentuan perjanjian itu harus dilterapkan dengan asas itikad baik dan konsumen telah melanggar UUPK Pasal 5 huruf (b) yang menyebutkan konsumen wajib untuk beritikad baik dalam melaksanakan transaksi pembayaran. Bentuk perlindongan hukum terhadap pelaku usaha dalam kasus tersebut sebagaimana dalam UUPK Pasal 6 huruf (b) yang menyatakan kalau pelaku usaha mempunyai untuk mendapatkan hak perlindungan hukum dari perilaku/tindakan konsumen yang beritikad tidak baik.

Menurut analisis penulis seharusnya pelaku usaha menerima perlindungan hukum dari perilaku/tindakan konsumen yang tidak beritikad baiiik, dimana bentuk perlindungan hukum yang dapat diterapkan pada kasus tersebut ialah perlindongan hukum secara represif yaitu merupakan perlindungan tahap akhir berupa sangsi seperti denda, penjara dan hukuman tambahan lainya, yang diberikan apabila sudah terjadi sengketa atau telah dilakukan suatu pelanggaran. Bentuk perlindungan hukum secara represif ini terhadap pelakuusaha dimana 
pelakuusaha dapat mengugat konsumen secara hukum perdata yaitu dengan gugatan wanprestasi dan pelaku usaha juga bisa menuntut konsumen secara jalur pidana atas tindakan pencemaran nama baik dalam Pasal 310-311 kitab undangundang hukum pidana.

\section{Putusan Mahkamah Agung RI No. 1041 K/Pdt.Sus-BPSK/2017 Terhadap} Perlindungan Hukum Pelaku Usaha Dari Konsumen Dalam Pembiayaan

\section{Konsumen}

Putusan Mahkamah Agung Republik Indonesia Nomor 1041 K/Pdt.SusBPSK/2017 merupakan akhir dari sengketa antara konsumen dan pelaku usaha pada pembiayaan konsumen, sebelum akhir ini peneliti akan menjelaskan putusan-putusan yang berawal dari BPSK Medan dan berlanjut ke Pengadilan Negeri Medan dan berakhir pada putusan MA yang akan dianalisi oleh penulis.

Kasus ini yang bermula pada bulan Desember 2013 Martha Sitorus (selanjutnya disebut konsumen) membeli satu unit kendaraan roda empat bertipe Avanza dengan mencicil kepada PT. Toyota Astra Finance Service (selanjutnya disebut pelaku usaha), yang beralamat di jalan Iskandar Muda Nomor 15 B Medan, dengan DP Rp 60.720.000. (enam puluh juta tujuh ratus dua puluh rupiah) dengan angsuran kewajiban konsumen setiap bulannya membayar Rp 4.301.000. (empat juta tiga ratus satu rupiah) selama 35 bulan.

Konsumen mulai melakukan pembayaran secara cicil yaitu tanggal 25 Desember 2013 sampai dengan 25 Oktober 2014 dimana selama 10 bulan secara terus menerus selalu lancar dalam melakukan pembayaran dan tidak pernah macet/tertunggak. Pada cicilan ke-12 tepatnya tanggal 25 November 2014 sampai 25 Mei 2015 konsumen mulai macet melakukan pembayaran, tetapi konsumen tetap membayar dengan dua kali dalam sekaligus termasuk bunga dan denda keterlambatan sesuai dengan bukti-bukti yang harus konsumen patuhi.

Puncaknya pada tanggal 25 Juni 2015 konsumen tidak dapat melakukan pembayaran cicilan mobil selama 7 bulan yaitu sampai 21 Desember 2015 
konsumen tidak dapat membayar cicilan, yang pada akhirnya pada tanggal 22 Desember 2015 konsumen mendapat uang dari pekerjaannya dan datang ke pelaku usaha berkeinginan membayar, akan tetapi pembayaran yang akan dilakukan oleh konsumen senilai Rp 30.000.000,00 (tiga puluh juta rupiah) itu tidak sesuai dengan instalment schedule yang sudah pelaku usaha tentukan dimana konsumen telat membayar selama 7 bulan ini pembayaran yang harus dibayar konsumen sebesar Rp 134.433.000,00 (seratus tiga puluh empat juta empat ratus tiga puluh tiga ribu rupiah) dimana ini telah sesuai dengan bunga.

Konsumen merasa kecewa dan mengajukan hal tersebut ke Badan Penyelesai Sengketa Konsumen (BPSK) kota Medan dengan dalil bahwa dilihat pelaku usaha telah melanggar hak-hak konsumen dan konsumen ingin tetap membayar tunggakan cicilan yang konsumen sanggupi, yang pada akhirnya Majelis di BPSK kota Medan mengeluarkan putusan pertama, menolak gugatan konsumen untuk seluruhnya, kedua dengan pertimbangan yaitu bahwa surat gugatan konsumen belum memenuhi syarat materil alasan gugatan konsumen yaitu syarat mutlak menuntut ganti rugi terhadap pelaku usaha sebagaimana dimaksud dalam Pasal 19 UUPK yaitu belum adanya kerugian konsumen dan bahkan Objek gugatan (Mobil Avanza) masih dikuasai oleh konsumen, oleh karenanya Majelis BPSK berpendapat gugatan konsumen tidak dapat menjadi pertimbangan dalam putusan ini. Konsumen lagi dan lagi merasa tidak puas dan tidak setuju dengan putusan BPSK kota Medan, mengajukan gugatan lagi ke Pengadilan Negeri Medan dengan dalil yang sama dengan sebelumnya, yang pada akhirnya pada pada 15 Agustus 2016 Pengadilan Negeri Medan memberikan putusan bahwa konsumen telah melakukan perbuatan cidera janji (wanprestasi) dan memberikan surat untuk penarikan objek yang dipersengketakan akan tetapi pada saat pelaku usaha akan menarik kendaraan yang bersangkutan, kendaraan tersebut berada ditangan pihak ketiga dan hal ini jelas telah menegaskan konsumen melanggar perjanjian yang dibuat. 
Konsumen dengan adanya putusan Pengadilan Negeri Medan tersebut mengajukan lagi gugatan di Mahkamah Agung Republik Indonesia (MA) pada tanggal 29 Agustus 2016, No. 74/Pdt/Kasasi/2016/Pn.Mdn dengan dalil yang sama, yang pada akhirnya MA pada tanggal 19 Oktober 2017 No.1041 K/Pdt.Sus-BPSK/2017 menjatuhkan putusan, pertama mengabulkan dan menerima permohonan kasasi dari pemohon kasasi Martha Sitorus (konsumen), kedua membatalkan putusan Pengadilan Negeri Medan Nomor 188/Pdt.Sus.BPSK/2016/PN.Mdn., tanggal 15 Agustus 2016.

Adapun pertimbangan hakim dalam memberikan putusan didasarkan pada pertama, bahwa berdasarkan asass dan tujuan dari Perlindungan Konsumen Pasal 2 UUPK menyebutkan perlindungan konsumen berasaskan manfaat, keadilan, keseimbangan, keamanan dan keselamatan konsumen, serta kepastian hukum hukum, ternyata berdasarkan asas tersebut Martha Sitorus (konsumen) tidak mendapatkan keadilan, tidak ada keseimbangan, keamanan serta kepastian hukum dari PT. Toyota Finance Service (pelaku usaha) dari perilaku konsumen yang memang tidak baik.

Menurut salah satu dosen Hukum Perlindungan Konsumen Universitas Trisakti, kedudukan konsumen dan pelaku usaha menurut beliau idealnya kalau berbicara mengenai hukum itu harus seimbang, maksud nya dimana posisi pelaku usaha ini biasanya lebih tinggi dari konsumen karena pelaku usaha ini lebih mendapatkan informasi lebih banyak dimana objek perjanjian transaksi yang dilakukan itu merupakan barang si pelaku usaha dan maksud dari keseimbangan dimana ketika pelaku usaha ingin melepas barang/jasanya ia harus memberikan informasi yang cukup untuk pada putusan konsumen menyetujui membeli produk pelaku usaha, misalnya ada perjanjian pengiriman barang/jasa diantara konsumen \& pelaku usaha para pihak juga harus memeberikan informasi sejelas mungkin guna kelancaran perjanjian tersebut. Jadi dalam Pasal 2 UUPK ini tidak hanya melihat dari sisi perlindungan hukum 
konsumen saja tetapi juga harus melihat perlindungan hukum dari pelaku usaha dan kedudukan kedua belah pihak itu haruslah seimbang antara hak \& kewajiban.

Pertimbangan hakim yang kedua ialah melihat dari itikad baik Martha Sitorus (konsumen) yaitu ia ingin melunasi sisa pembayaran tunggakan yang selama ini tidak dibayarkan kepada pelaku usaha. Menurut Menurut Dr. Susanti Adi Nugroho, S.H., M.H. Dosen Hukum Penyelesaian Sengketa Konsumen, Universitas Tarumanagara, asas itikad baik itu tidak hanya di tujukan ke konsumen saja tetapi, semua tindakan itu harus didasarkan pada itikad baik, seperti kesepakatan itu terlepas pada isi suatu kesepakatan dimana landasannya itu adalah asas itikad baik. Kedudukan itikad baik ini dalam UUPK harus dilihat dari segala aspek antara pelaku usaha dan konsumen didalam perjanjian karena kalau dilihat dari satu sisi saja akan menimbulkan ketidakadilan dan dapat merugikan salah satu pihak.

Beliau juga memberikan pendapat dalam kasus pembiayaan konsumen yang tidak beritikad baik dimana konsumen ini tidak melaksanakan kewajibannya, pada umumnya perkara dalam pembiayaan konsumen ini atas konsumen yang tidak melaksanakan kewajibannya itu dapat dilihat dari klausula perjanjian pembiayaan misalnya selama tiga bulan konsumen tidak membayar cicilan, objek dalam perjanjian pembiayaan dapat diambil dan dilelang sebagai jaminan utang, tetapi terkadang hal ini tidak hanya dilihat dari itikad baik dimana konsumen ini biasanya tidak mempunyai uang ini terlepas dari itikad baik juga hal itu dapat dikatakan sebagai wanprestasi. Dimana tidak hanya dapat dilihat dari ketentuan itikad baik dari konsumen tetapi juga dari kondisi apakah konsumen ini masih mampu melaksanakan kewajibannya sebagaimana yang telah diperjanjikan dengan pelaku usaha.

Ada empat poin yang diklasifikasikan oleh beliau dari wanprestasi diantaranya Pertama, tidak melaksanakan prestasi seperti yang dijanjikan, 
seperti kententuan pembayaran cicilan yang dilakukan konsumen, Kedua, terlambat dalam melaksanakan suatu prestasi, Ketiga, kelebihan waktu seperti adanya suatu proyek pembangunan rumah yang diperjanjikan oleh konsumen dengan perusahaan, dimana yang seharusnya suatu rumah tersebut harus selesai dalam jangka waktu 3 bulan tetapi, pada bulan yang telah ditentukan itu rumah tersebut belum jadi dan perusahaan dapat dinyatakan wanprestasi, Keempat, pihak konsumen melakukan suatu perbuatan yang dimana perbuatan tertentu itu dilarang dalam suatu perjanjian. Jadi kalau hal konsumen yang tidak membayar cicilan dalam suatu perjanjian kredit dengan perusahaan pembiayaan dapat dikatakan sebagai wanprestasi. Sanksi hukum bagi konsumen yang bertindak tidak bertitikad tidak baik menurut beliau hal itu dapat dilihat dari suatu perjanjian antara konsumen dengan pihak pelaku usaha, misalnya pembiayaan mobil/motor kalau konsumen tidak membayar satu bulan saja objek dari pembiayaan itu dapat diambil oleh pelaku usaha.

Pertimbangan pertama hakim menimbang bahwa PT. Toyota Astra Finance Service (pelaku usaha) telah mengabaikan ketentuan Pasal 2 UUPK Martha Sitorus (konsumen) sebagaimana Pasal 2 UUPK meyebutkan perlindungan konsumen berasaskan manfaat, keadilan, keseimbangan, keamanan dan keselamatan konsumen, serta kepastian hukum hukum, ternyata atas asas tersebut Martha Sitorus (konsumen) tidak mendapatkan keadilan, tidak ada keseimbangan, keamanan serta kepastian hukum dari PT. Toyota Finance Service (pelaku usaha). Menurut penulis kalau di lihat dari asas perlindungan konsumen, asas tersebut tidak hanya di tujukan kepada konsumen saja tetapi juga melihat dari pelakuusaha. dimana dalam kasus ini PT. Toyota Astra Finance Service (pelaku usaha) juga tidak mendapatkan keadilan, keseimbangan, kemanfaatan dan kepastian hukum yang dimana konsumen telah beritikad tidak baik. 
Pertimbangan yang kedua ialah Majelis Hakim melihat dari itikad baik Martha Sitorus (konsumen) yaitu ia ingin melunasi sisa pembayaran tunggakan yang selama ini tidak dibayarkan kepada pelaku usaha. Menurut penulis pertimbangan Majelis Hakim ini tidak dapat dijadikan dasar karena kalau dilihat dari itikad baik Martha Sitorus (konsumen), bahwa konsumen yang terlebih dahulu melanggar ketentuan itikad baik tersebut dimana konsumen tidak melakukan pembayaran selama 7 bulan kepada pelaku usaha. dan dalam UUPK sendiri Pasal 5 huruf $\mathrm{b}$ yang menyebutkan kewajiban konsumen untuk beritikad baik dalam melakukan transaksi pembelian barang dan atau jasa

Menyangkut dan berdasarkan kewajiban konsumen beritikad baik hanya itu tertuju pada transaksi pembelian barang \& jasa, hal ini tentu saja dilihat dari sebab karena bagi konsumen, kemungkinan untuk dapat merugikan pelaku usaha mulai pada saat melakukan transaksi dengan pelaku usaha, jadi berdasarkan kewajiban ini adalah kosumen harus taat saat melakukan pembayaran dalam transaksi dengan pelaku usaha. Selain itu dalam UUPK Pasal 5 huruf (c) yang menyebutkan adanya suatu kewajiban dimana konsumen harus membayar sesuai dengan nilai tukar yang disepakati. Kewajiban konsumen harus membayar sesuai dengan nilai tukar yang disepakati dengan pelaku usaha, adalah hal yang sudah wajib dan semestinya demikian. Hal ini telah menjelaskan bahwa konsumen telah terlebih dahulu melanggar Pasal 5 huruf (b) dan (c) UUPK dimana konsumen tidak beritikad baik dan tidak melakukan pembayaran sesuai nilai tukar yang telah disepakati oleh pelaku usaha.

Pengertian dan arti dari itikad baik dalam Pasal 1338 ayat (3) kitab undangundang hukum perdata yang berarti melalkukan pelaksanaan suatu perjanjian dengan itikad baik, ialah merupakan suatau sifat yang dinamis. Memiliki arti para pihak dalam melaksanakan perjanjiiaan harus melihat dari kejujuran dan berjalan dalam hati sanubari seorang manusia. Manusia selalu mengingat bahwa 
sebagai suatu anggota masyarakat harus menjauhkan diri dari merugikan pihak lain. Lebih lanjut untuk memahami asas ini dijelaskan unsur-unsur apa saja yang dapat digunakan sebagai pembatasan dalam penggunaaan asas kebebasan berkontrak sebagaimana diisyaratkan di dalam ketentuan Pasal 1338 ayat (3) kitab undang-undang hukum perdata antara lain pertama unsur kejujuran, kejujuran merupakan sesuatu hal yang sangat penting dalam soal pelaksanaan suatu perjanjian, dimana suatu perjanjian harus dilaksanakan dengan kejujuran para pihak yang membuat dan melaksanakaannya.

Kejujuran dalam pelaksanaan perjanjian harus dibedakan dari pada kejujuran pada waktu dimulai berlakunya pengikatan hukum, seperti hal kejujuran memang merupakan sebagai salah satu syarat guna memperoleh milik perjanjian yang lalu bezit togoeder trouw didalam Pasal 1963 kitab undangundang hukum perdata sebagai syarat memperoleh milik barang secara verjaring). Kejujuran dalam waktu mulainya perjanjian ialah dimana parapihak harus jujur atas memberikan identitas atas dimulai nya suatu perjanjian. Dalam terlaksananya suatu perjanjian kejujuran terletak pada keadaan jiwa dan hati manusia, akan tetapi titik dasar dari kejujuran ini terletak pada suatu tindakan yang dilakukan oleh kedua belah pihak dalam hal melaksanakan janji, kedua belah pihak harus selalu memperhatikan hal ini dan tidak boleh mempergunakan kelalaian pihak lain untuk menguntungkan diri pribadi. Kejujuran dalam kasus ini bahwa Martha Sitorus (konsumen) telah melanggar unsur kejujuran yaitu dengan memberikan kenyataan palsu dimana ia tidak dapat membayar tunggakan cicilan dari PT. Toyota Astra Finance Service (pelaku usaha) yang dimana konsumen menyatakan pendapat kalau tidak dapat membayar selama 7 bulan, tetapi bulan ke 8 ia datang ke kantor pelaku usaha dan ingin melaksanakan pembayaran secara sepihak dimana hal ini jelas merugikan pelaku usaha. 
Kedua unsur kepatuhan, kepatuhan juga salah satu unsurr yang memang harus ada dalam suatu perjanjian, karena hal ini berguna agar jalannya suatu perjanjian tersebut. Syarat kepatuhan ini sebetulnya berdasar pada suatu sifat peraturan hukum pada umumnya, yaitu usaha untuk mengadakan keseimbangan didalam suatu perjanjian, dimana bahwa kedua belah pihak harus mematuhi dalam melaksanakan suatu perjanjian. Martha Sitorus (konsumen) tidak memenuhi unsur kepatuhan karena ia tidak melakukan pembayaran yang sebagaimana hal ini merupakan kewajiban konsumen guna memenuhi prestasinya ke PT. Toyota Astra Finance Service Medan (pelaku usaha). Kepatuhan disini dilihat dari dimana konsumen tidak melaksanakan pembayaran selama 7 bulan dan sangat jelas konsumen telah melanggar unsur kepatuhan.

Ketiga unsur kepatutan, kepatutan ini merupakan unsur yang juga ada dalam asas itikad baik yang dimana kepatutan ini tidak dapat mengubah isi dari perjanjian tetapi dapat menetapkaan apa maksud sebenarnya dari isi perjanjian itu, sebab mengartikan tidakan lain adalah mencari maksud dari para pihak, tidak hanya melihat dari kata-kata perjanjian, tetapi semua yang ada dibelakang katakata tersebut. Pasal 1339 kitab undang-undang hukum perdata menyebutkan kalau dalam suatu perjanjian parapihak itu tidak hanya terikat terhadap yang secara tegas disetujui didalam perjanjian tersebut, tetapi juga terikat oleh kepatutan, kebiasaan dan undang-undang. Kepatutan disini melihat dari kedua orang dalam perjanjian dalam melaksanakan hak serta kewajibanya dalam suatu perjanjian harus dinilai dengan patut, yang dimana perbuatan para pihak dalam menetapkan isi suatu perjanjian harus dinilai apakah perbuatan itu melanggar atau tidak dari hak dan kewajiban para pihak. Unsur kepatutan disini peneliti menganggap Martha Sitorus (konsumen) tidak memenuhi unsur kepatutan dimana konsumen menunggak selama 7 bulan pembayaran dan ingin kembali melunasi sisa tunggakan pembayaran dengan secara sepihak menentukan uang yang akan dibayarkan ke PT. Toyota Astra Finance Service (pelaku usaha). 
Berdasarkan analisis peneliti sependapat dengan salah satu dosen di universitas tarumanagara, dimana beliau yang juga pernah menjabat menjadi hakim agung pada tahun 2003 ini, berpendapat atas Putusan Mahkamah Agung Republik Indonesia (MA) No.1041 K/Pdt.Sus-BPSK/2017 dengan hasil putusan tersebut menurut beliau pertimbangan hakim tersebut tidak tepat kalau mendasarkan atas itikad baik konsumen, hal ini dapat dilihat dari awal konsumen telah melanggar ketentuan itikad baik dimana konsumen ini dalam 7 bulan tidak membayar cicilan, bahwa sebenarnya yang beritikad tidak baik ini adalah konsumen. Itikad baik harus juga dilihat dari sudut pihak yang melanggar asas tersebut.

\section{PENUTUP}

\section{A. Kesimpulan}

1. Pelaku usaha tidak menerima perlindungan hukum atas perbuatan Martha Sitorus (konsumen) dimana ia tidak beritikad baik didalam konsumen pembiayaan, sebagaimana hal ini dalam Pasal 6 huruf (b) pelaku usaha mempunyai suatu hak untuk mendapatkan perlindongan hukum dari tindakan konsumen yang tidak beritikad baik.

2. Putusan Mahkamah Agung Republik Indonesia Nomor 1041 K/Pdt.SusBPSK/2017 menurut peneliti Majelis Hakim kurang tepat kalau memberikan pertimbangan dari itikad baik Martha Sitorus (konsumen), karena dari awal konsumen ini telah terlebih dahulu melanggar itikad baik dengan tidak membayar cicilan kendaraan selama 7 bulan.

\section{B. Saran}

1. Sebaiknya Martha Sitorus (konsumen) harus melaksanakan itikad baik atas perjanjian pembiayaan konsumen dengan PT. Toyota Astra Finance Service (pelaku usaha), karena hal ini merupakan suatu kewajiban konsumen sebagaimana dalam Pasal 5 huruf (b) UUPK. 
2. Pada Putusan Mahkamah Agung Republik Indonesaia Nomor 1041 K/Pdt.Sus-BPSK/2017 Majelis Hakim seharusnya melihat lagi alur sengketa antara Martha Sitorus (konsumen) dan PT. Toyota Astra Finance Service (pelaku usaha) dimana Majelis Hakim harus melihat lagi siapa yang terlebih dahulu melanggar itikad baik hal ini guna memberikan suatu putusan yang adil dan tidak merugikan para pihak.

\section{DAFTAR PUSTAKA}

\section{A. Buku}

Fuady, Munir. Hukum tentang Pembiayaan (dalam teori dan praktek). (Bandung: Citra Aditya Bakti, 2002.)

HS, H.Salim. Perkembangan Hukum Kontrak Di luar KUH Perdata Buku Dua. (Jakarta: PT Raja Grafindo Persada, 2008.)

Muhammad, Abdul Kadir dan Rilda Murniati. Segi Hukum Lembaga Keuangan dan Pembiayaan. (Bandung: Citra Aditya Bakti, 2000.)

Muljadi, Kartini dan Gunawan Widjaja. Perikatan Yang Lahir dari Perjanjian. (Jakarta: Rajawali Pers, 2013.)

Prodjodikoro, R. Wirjono. Asas-Asas Hukum Perdata. (Bandung: Sumur, 1992.) 2002.)

, R. Wirjono. Asas-asas Hukum Perjanjian. (Bandung: Mandar Maju,

Soeroso, R. Perjanjian Di Bawah Tangan. (Jakarta: Sinar Grafika, 2010.)

Subekti. Hukum Perjanjian. (Jakarta: Intermasa, 1997.)

Sunaryo. Hukum Lembaga Pembiayaan. (Jakarta: Sinar Grafika, 2009.)

Suharnoko. Hukum Perjanjian Teori dan Analisa Kasus. (Jakarta: Prenada Media, 2014.)

Syahrani, Riduan. Seluk Beluk dan Asas-Asas Hukum Perdata. (Bandung: Alumni, 2006.) 


\section{B. Jurnal:}

Winarni, Luh Nila, "Asas Itikad Baik Sebagai Upaya Perlindungan Konsumen Dalam Perjanjian Pembiayaan”. Jurnal Ilmu Hukum, Vol. 11, No. 21 Tahun 2015. 